\title{
Salt Tolerance of Cheese Culture Lactococcus lactis R-604 as Influenced by Prior Salt Exposure and Lactose Deprivation
}

\author{
Ernesto E. Gonzalez, Kayanush Aryana* \\ School of Nutrition and Food Sciences, Louisiana State University, Baton Rouge, USA \\ Email: ^karyana@agcenter.1su.edu
}

How to cite this paper: Gonzalez, E.E. and Aryana, K. (2018) Salt Tolerance of Cheese Culture Lactococcus lactis R-604 as Influenced by Prior Salt Exposure and Lactose Deprivation. Food and Nutrition Sciences, 9, 633-641.

https://doi.org/10.4236/fns.2018.96048

Received: February 13, 2018

Accepted: June 3, 2018

Published: June 6, 2018

Copyright $\odot 2018$ by authors and Scientific Research Publishing Inc. This work is licensed under the Creative Commons Attribution International License (CC BY 4.0).

http://creativecommons.org/licenses/by/4.0/

\section{c) (i) Open Access}

\begin{abstract}
Manufacture of some cheeses involves the use of Lactococcus lactis. During processing bacteria are subjected to environmental stresses such as acid and salt osmotic conditions. Identifying procedures and mechanisms to develop resistance to these environmental stresses, specifically salt, is important to improve the culture's growth and performance during food manufacture and storage. Hypothesis was whether salt tolerance of Lactococcus lactis R-604 can be enhanced. Objective was to study the influence of prior salt exposure and lactose deprivation on salt tolerance of $L$. lactis. The culture was subjected to mild stress induced by lactose starvation or prior salt exposure for 24 hours aerobically at $30^{\circ} \mathrm{C}$. A control was conducted without any stress. Cells that were prior mild stressed by lactose starvation or prior salt exposure were transferred to $\mathrm{M} 17$ broth with 5 concentrations of $\mathrm{NaCl}(0,1,3,5$ and $7 \%$ $\mathrm{w} / \mathrm{v}$ ) and incubated aerobically at $30^{\circ} \mathrm{C}$. Plating was conducted immediately after inoculation and every 24 hours for 5 days in M17 agar supplemented with $0.5 \%$ of lactose and incubated aerobically at $30^{\circ} \mathrm{C}$ for 48 hours. Three replications were conducted. There was no need for lactose to grow this culture in $\mathrm{M} 17$ broth and it could tolerate prior exposure to $3 \% \mathrm{w} / \mathrm{v} \mathrm{NaCl}$ in media without affecting its growth at different salt concentrations. Culture that was exposed to lactose starvation and then subsequently grown in $3 \% \mathrm{w} / \mathrm{v}$ $\mathrm{NaCl}$, at day 3 showed enhanced salt tolerance which can be recommended as a pretreatment condition for obtaining daughter cells with improved salt tolerance.
\end{abstract}

\section{Keywords}

Cheese Culture, Salt, Tolerance

\section{Introduction}

In many dairy products salt is used as a preserving agent, as a proteolysis en- 
hancer, and a desirable flavor contributor. Salt can also affect the quality and flavor development in the ripening process, since it inhibits microbial activity of both spoilage and beneficial bacteria such as lactic acid bacteria and probiotics [1]. Salt concentrations in cheeses can range from as low as 0.7 in some natural cheeses to as high as $6 \%$ in pickled cheeses such as Domiati and Sikma. Salt concentration of $3 \%$ would be an average stress condition for cheese culture bacteria. Salt concentrations above $6 \%$ can reduce the growth of $L$. lactis by $80 \%$ and reduce the acid production by $50 \%$ [2]. Uguen et al. [3], while studying the influence of the presence of osmoprotectant (i.e. glycine betaine) on the growth of $L$. lactis ADRIA $85 \mathrm{LO} 30$ reported that a salt concentration of $0.5 \mathrm{M}$ in chemically defined medium reduced the growth rate by $70 \%$.

Higher concentration of salt in a medium will cause an osmotic stress in bacteria, since it creates an imbalance of ion $\left(\mathrm{K}^{+}, \mathrm{Na}^{+}\right.$and $\left.\mathrm{Cl}^{-}\right)$concentrations in the cytoplasm of the cell and its environment [4]. Dehydration of the cell can be produced by the release of water through the permeable cell membrane to maintain homeostasis [5]. Also this permeability of the membrane allows salt ions to move into the cytoplasm affecting cell functions such as gene expression, protein synthesis, and water retention which are necessary for cell nutrition and stability [6]. Fatty acid composition of cellular membrane can be modified to protect the cell from hyperosmotic conditions [7]. An increase in the ratio of trans to cis fatty acids has been also observed in osmotically stressed cells [8]. An increase in cyclopropane fatty acid $(\Delta \mathrm{C} 19: 0)$ and lower levels of oleic acid (C18:1), which has been observed in L. lactis, are considered to enhance betaine transport and regulate permeability [9].

Resistance to stress can also be achieved by adaptation which is an evolutionary process whereby an organism becomes better able to live under certain conditions [10]. Prior exposure to sub-lethal levels of stress turns the cell more resistance to lethal levels of the same stress [11]. For instance, L. lactis strains cultivated at $\mathrm{pH} 5$ grow better in higher acidic conditions. Adaptation to heat stress has also been found in L. lactis. Exposure to non-lethal temperatures for short times improved survival rate at higher than normally lethal temperatures [6]. Adaptation can also be induced for cold temperatures. Lactobacillus strains increase freezing survival in about $2 \log$ after a $15^{\circ} \mathrm{C}$ treatment for 2 hours [12]. A study using L. lactis ssp. Lactis and ssp. Cremoris showed that pre-exposure to mild acid conditions, low heat shock and low bile salt concentration increase the viability of the culture to lethal levels of the same stress [13].

Another way to increase stress resistance is by subjecting bacterial cells into a medium with low or no nutrients, or where their availability is reduced due to modifications in environment such as extreme $\mathrm{pH}$ or low water activity which leads to a cell starvation [7]. Lactic acid bacteria react under starvation by modifying in their cell morphology, causing them to shrink and by slowing the rate of cell division. Modifications in the cell membrane fatty acid composition and decreased protein synthesis also occur [14]. Carbohydrate starvation usually 
leads to a quick exponential growth, however when cell reserves are gone they become a viable dormant culture [15]. Resistance to this stress is determined by lipid membrane integrity, cytoplasmic enzymes activity, and CcpA gene regulation [9]. After starvation, Gram positive bacterial expression of sigma factor is increased, Sigma factor is also involved in the control of catalase synthesis (katE) and the transport of osmoprotectans such as proline (opuE) [16]. Glucose starved cultures of Lactococ cuslactis subsp. lactis IL1403 were found to develop better survival rate to ethanol stress at $20 \% \mathrm{v} / \mathrm{v}$, oxidative stress at $15 \mathrm{mM}$, low heat stress at $52^{\circ} \mathrm{C}$ [14]. The overlap in stress induced proteins can increase the cell's resistance to other stresses [17].

The influence of prior salt $(\mathrm{NaCl})$ exposure and lactose deprivation on salt tolerance of the cheese bacterium Lactococcus lactis R-604 is not well understood. The hypothesis was whether the subjection to prior mild stress conditions would enhance salt tolerance of Lactococcus lactis R-604. The objective was to study the effect of two different stress exposures (prior $\mathrm{NaCl}$ exposure and lactose deprivation) on the growth of Lactococcus lactis R-604 in five levels of $\mathrm{NaCl}(0,1$, $3,5$ and $7 \% \mathrm{w} / \mathrm{v})$.

\section{Materials and Methods}

\subsection{Experimental Design}

The stress conditions i.e. $3 \% \mathrm{w} / \mathrm{v} \mathrm{NaCl}$ for prior salt exposure and no lactose for lactose starvation were created for 24 hours at $30^{\circ} \mathrm{C}$ in M17 broth. The control did not have any stress condition. After subjection to stress conditions or no stress condition (control) the cultures were transferred to five $\mathrm{NaCl}$ concentrations $(0,1,3,5$ and $7 \% \mathrm{w} / \mathrm{v})$. Bacterial counts were determined every 24 hours for 5 consecutive days. The experiments were conducted in duplicate and repeated three times. Data were analyzed as a complete randomized split plot design with repeated measures over time.

\subsection{Preparation of Media}

The M17 broth was used for all samples and it was prepared according to manufacturer's specifications as follows: 37.25 grams of M17 broth powder (Fisher Scientific, Fair Lawn, NJ) was diluted in $1 \mathrm{~L}$ of distilled water. Then $94 \mathrm{~mL}$ of the solution was poured into different bottles and sterilized at $121^{\circ} \mathrm{C}$ for $15 \mathrm{~min}$ at 15 psi. A $10 \%$ w/v lactose solution (Fisher Scientific, Fair Lawn, NJ) was prepared separately and sterilized under the same conditions. After autoclaving, 5 $\mathrm{mL}$ of the sterile lactose solution was aseptically added into the sterile M17 bottles except for lactose starvation. Then the bottles were tempered at $30^{\circ} \mathrm{C}$ in an aerobic incubator until temperature of $30^{\circ} \mathrm{C}$ was reached. M17 agar supplemented with $0.5 \%$ lactose was used for all samples.

\subsection{Control}

Pure culture of Lactococcus lactis DVS culture R-604 (CHR HANSEN, Milwau- 
kee, WI) was thawed and inoculated in M17 broth supplemented with $0.5 \% \mathrm{w} / \mathrm{v}$ lactose and immediately plated (Day 0) and then incubated aerobically for 24 hours at $30^{\circ} \mathrm{C}$. Then $1 \mathrm{~mL}$ sample of this dilution was transferred to five different bottles containing sterile $\mathrm{M} 17$ broth with $\mathrm{NaCl}$ (Fisher Scientific, Fair Lawn, NJ) at $0,1,3,5$, and $7 \% \mathrm{w} / \mathrm{v}$. The inoculated M17 broths with the five salt concentrations were incubated aerobically at $30^{\circ} \mathrm{C}$ [18] for 5 days. Samples were drawn immediately after inoculation and every 24 hours for 5 days. Samples were plated using M17 agar with $0.5 \%$ w/v lactose. Pour plates were aerobically incubated at $30^{\circ} \mathrm{C}$ for 3 days. Colonies were counted after the 3 days incubation.

\subsection{Prior Salt Exposure of the Culture}

Pure culture of Lactococcus lactis R-604 was thawed and inoculated in M17 broth containing $3 \% \mathrm{w} / \mathrm{v} \mathrm{NaCl}$ and $0.5 \%$ lactose and immediately plated (Day 0 ) and then incubated aerobically for 24 hours at $30^{\circ} \mathrm{C}$. After this exposure to salt for 24 hours, which was the prior salt exposure condition, $1 \mathrm{~mL}$ of sample was transferred to five different bottles containing sterile M17 broth supplemented with $0.5 \%$ lactose and five concentrations of $\mathrm{NaCl}$ at $0,1,3,5$, and $7 \% \mathrm{w} / \mathrm{v}$. The inoculated broths with the five salt concentrations were incubated aerobically at $30^{\circ} \mathrm{C}$ for 5 days. Samples were taken immediately after inoculation and every 24 hours for 5 days. Bacterial counts $(\mathrm{CFU} / \mathrm{mL})$ were determined by plate counting in M17 agar supplemented with $0.5 \% \mathrm{w} / \mathrm{v}$ lactose. Pour plates were incubated aerobically at $30^{\circ} \mathrm{C}$ and counted after 72 hours.

\subsection{Lactose Starvation of the Culture}

Pure culture of Lactococcus lactis R-604 was thawed and inoculated in M17 broth containing no lactose and immediately plated (Day 0) and then incubated aerobically for 24 hours at $30^{\circ} \mathrm{C}$. After this deprivation of lactose for 24 hours, which was the lactose starvation stress condition, $1 \mathrm{~mL}$ of sample was transferred to five different bottles containing sterile M17 broth supplemented with $0.5 \%$ lactose and five concentrations of $\mathrm{NaCl}$ at $0,1,3,5$, and $7 \% \mathrm{w} / \mathrm{v}$. The inoculated broths with the five salt concentrations were incubated aerobically at $30^{\circ} \mathrm{C}$ for 5 days. Samples were taken immediately after inoculation and every 24 hours for 5 days. Bacterial counts $(\mathrm{CFU} / \mathrm{mL})$ were determined by plate counting in M17 agar supplemented with $0.5 \% \mathrm{w} / \mathrm{v}$ lactose. Pour plates were incubated aerobically at $30^{\circ} \mathrm{C}$ and counted after 3 days.

\subsection{Statistical Analysis}

Data were analyzed as a complete randomized design split plot with repeated measures over time using Proc Glimix of SAS (version 9.3 SAS Institute Inc., Cary, NC). Stress conditions, salt concentrations, and time of exposure were fixed effects, whereas replicates were random effects. Statistical analysis was done separately for each group of experiments. Significant differences were tested with least square means at $P<0.05$ for main effects (stress conditions, 
time and salt concentration) and the interaction effect (stress conditions $\times$ salt concentrations $\times$ time of exposure). Significant differences $(P<0.05)$ between pair comparisons of interest were analyzed using a LS Means.

\section{Results and Discussion}

The effect of each stress condition on the salt tolerance of Lactococcus lactis R-604 was evaluated by bacterial counts and is presented in Table 1. The two way interaction between salt concentration and time (days) had a significant $(P<0.05)$ effect which meant that cell counts of $L$. lactis R-604 depended on the salt concentration over the days of exposure (Table 2).

Table 1. Least Square Means (LS Means) expressed as log CFU/ml of salt tolerance of Lactococcus lactis R-604 after 24 hours of prior exposure to $3 \% \mathrm{NaCl}$ or lactose deprivation.

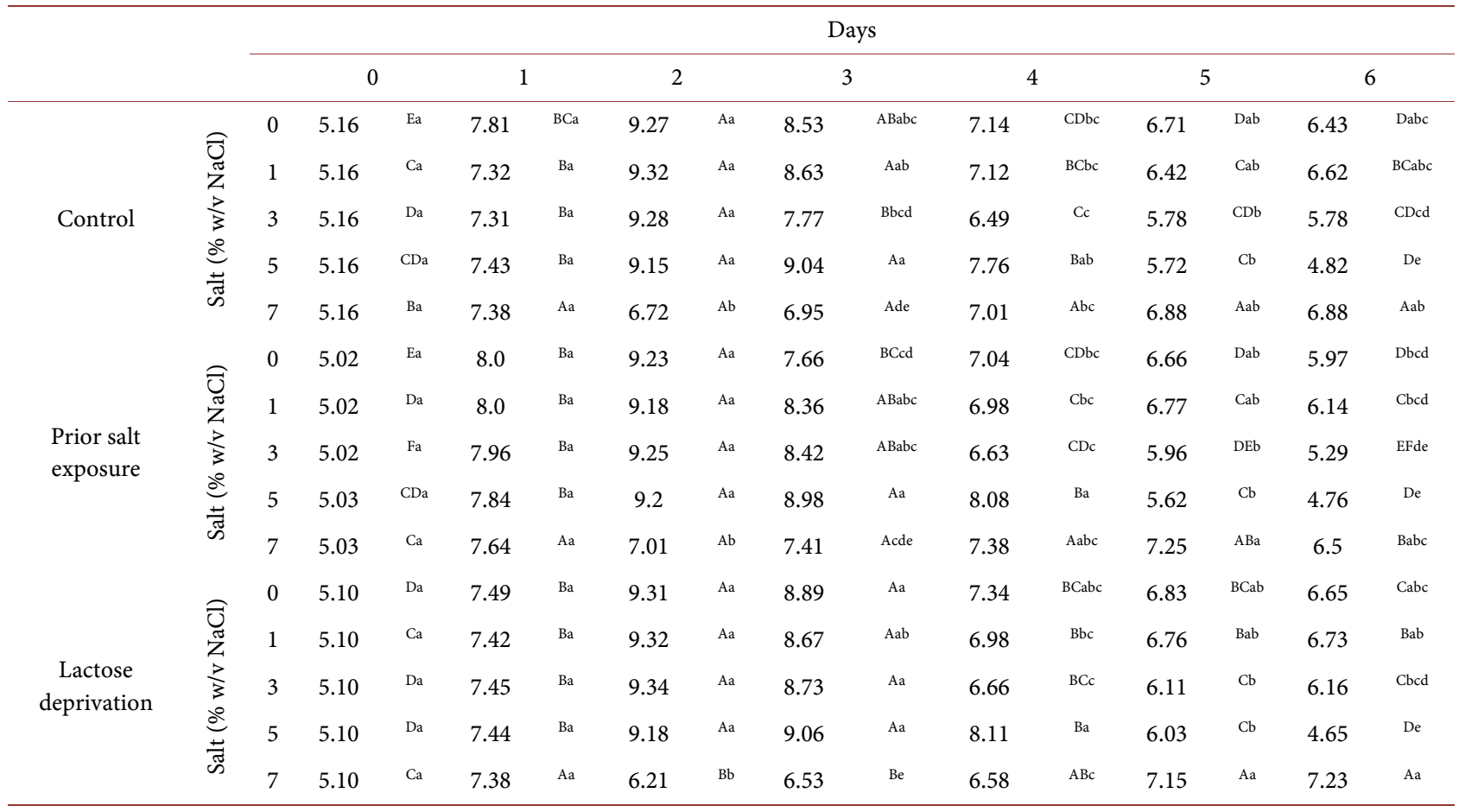

${ }^{\mathrm{ABC}}$ LS Means with different capital letters within a row are significantly different $(P<0.05) .{ }^{\text {abc }}$ LS Means with different lowercase letters within a column to include all treatments are significantly different. $(P<0.05)$.

Table 2. Probability > F Value for fixed effects of the salt tolerance of Lactococcus lactis R-604 influenced by 24 hours osmotic adaptation or lactose deprivation.

\begin{tabular}{cc}
\hline Effect & P F F \\
\hline Stress conditions & 0.9002 \\
Salt Concentration & 0.0010 \\
Stress conditions ${ }^{\star S a l t ~ c o n c e n t r a t i o n s ~}$ & $<0.6911$ \\
Days & 0.0823 \\
Stress conditions ${ }^{\star}$ Days & $<0.0001$ \\
Salt concentrations ${ }^{\star}$ Days & 0.9984 \\
Stress conditions ${ }^{*}$ Salt concentrations ${ }^{\star}$ Days &
\end{tabular}




\subsection{Salt Tolerance of Lactococcus lactis $\mathrm{R}-604$ as Influenced by 24 Hours of Incubation under Ideal/Non Stressed (Control) Conditions}

The growth of $L$. lactic R-604 under different salt concentration after 24 hours of incubation under ideal conditions (M17 broth supplemented with $0.5 \%$ lactose at $30^{\circ} \mathrm{C}$ ) is shown in Table 1 . All samples had an exponential growth of 2 logs during the 24 hours ( 1 day) incubation period. For $0,1 \%, 3 \%$ and $5 \%$ an exponential phase was observed during days 1 and 2, while for 7\% the exponential phase was observed only at day 1 . Stationary phase was observed at day 3 for 0,1 and $5 \%$, while their decline phases were observed at days $4,5,6$. For the $3 \%$ the decline phase started at day 3 and continued to day 6 . On day 6 the bacterial counts at $5 \%$ were significantly the lowest compared to $0,1 \%, 3 \%$ and $7 \%$.After day 1 , the cells at $7 \% \mathrm{w} / \mathrm{v} \mathrm{NaCl}$ did not grow as they did not show any significant change in counts over the 6 days. The growth inhibition produced by the sudden osmotic stress could cause the loss of cell turgor pressure and therefore its dehydration. Thus affecting the bacteria's primary functions and reducing the reproduction rate [4]. The accumulation of compatible solutes has been proposed as a mechanism to overcome hyperosmotic conditions for many microorganisms [19], particularly glycine betaine and proline for lactic acid bacteria [20] [21].

\subsection{Salt Tolerance of Lactococcus lactis R-604 as Influenced by Prior Salt Exposure}

There were no significant $(P>0.05)$ differences in bacterial counts between the cells prior exposed to $\mathrm{NaCl}$ and the cells that were not (control) (Table 1). According to Kilstrup et al. [22], cells usually reduce metabolic activity in order to start an adaptation process. Kim et al. [18] showed that cells in stationary phase are more resistant to stress than cells in exponential phase. Cells in this study were in stationary phase at the time of transfer to the different salt concentrations. Kim et al. [18] stated that in order to generate an adaptation response cells must be subjected to a mild stress for an adequate amount of time, thus allowing them to synthetize necessary proteins for stress adaptation. These data show that prior exposure to $3 \% \mathrm{NaCl}$ for 24 hours was not detrimental for the growth of $L$. lactis R-604.

\subsection{Salt Tolerance of Lactococcus lactis $\mathrm{R}-604$ as Influenced by Lactose Starvation}

Lactococcus lactis $\mathrm{R}-604$ cells after lactose starvation grew at the same rate as Control regardless of the salt concentration. The only significant $(P<0.05)$ difference found was on day 3 , at $3 \% \mathrm{w} / \mathrm{v} \mathrm{NaCl}$ (Table 1), where the lactose deprived cells showed 1 log higher counts than the Control, at the same salt concentration on the same day (Table 1). The main proposed explanation for the cross-protection that starvation stress can confer to bacteria is the pattern change in gene expression. This leads to different polypeptides synthesis, stress induced proteins, that are produced under more than one environmental stres- 
sor [16]. However, a study involving glucose starved organisms failed to improve resistance to hydrogen peroxide stress, since the specific KatA and KatE catalase enzymes were lower than the catalase activity generated after an oxidative adaptation [23].

Hartke et al. [14] showed that resistance to heat, ethanol, low acid and hydrogen peroxide can be achieved by stationary phase cells of $L$. lactis grown under lactose starvation. Other microorganisms such as Enterococcus faecalis and Listeria monocytogenes, after complete glucose starvation, can develop resistance to heat, hydrogen peroxide, bile salt and sodium chloride [17] [24]. Jenkins et al. [25] showed that E. coli can develop resistance to osmotic shock at $2.5 \% \mathrm{w} / \mathrm{v}$ $\mathrm{NaCl}$ after 4 hours of glucose starvation. Other ways to induce starvation stress include, growing the cells in suspension media such as saline solution $(0.08 \%$ $\mathrm{w} / \mathrm{v} \mathrm{NaCl}$ ), peptone water, or Phosphate Buffer Saline solution (PBS). However, Hartke et al. [14] stated that small amounts of carbohydrates $(0.1 \% \mathrm{w} / \mathrm{v}$ glucose) in media can be used rapidly by cells and trigger stationary phase quicker and therefore helping the cells to adapt better to further stress conditions.

It must also be considered, that during starvation treatments amino acids must be present in media as a precursor for protein synthesis to obtain better stress adaptation [7]. Prior exposure of L. lactis R-604 in 3\% w/v NaCl or lactose starvation and subsequent use of treated cells in up to $5 \% \mathrm{w} / \mathrm{v} \mathrm{NaCl}$ did not have a negative influence on its growth which could be industrially feasible for high salt $(5 \% \mathrm{w} / \mathrm{v} \mathrm{NaCl})$ foods.

\section{Conclusion}

Prior salt exposure to $3 \% \mathrm{w} / \mathrm{v}$ or lactose starvation was not detrimental to this culture and even under lactose starvation conditions it performed similar to control maintaining comparable counts in salt concentrations as high as $7 \% \mathrm{w} / \mathrm{v}$. On day 3 at $3 \% \mathrm{w} / \mathrm{v} \mathrm{NaCl}$, the lactose deprivation resulted in enhanced salt tolerance and this can be recommended as a pretreatment condition for obtaining daughter cells with improved salt tolerance.

\section{Acknowledgements}

This projected was funded by USDA Hatch funds and the Louisiana State University Agricultural Center.

\section{References}

[1] Guinee, T. (2004) Salting and the Role of Salt in Cheese. International Journal of Dairy Technology, 57, 99-109. https://doi.org/10.1111/j.1471-0307.2004.00145.x

[2] Tripathi, A., Misra, A. and Chander. H. (2003) Induction of Salt Tolerance in Lactococcus lactis ssp. cremoris by Adaptation. Journal of Food Science and Technology, 40, 525-527.

[3] Uguen, P., Hamelin, J., Le Pennec, J.-P. and Blanco, C. (1999) Influence of Osmolarity and the Presence of an Osmoprotectant on Lactococcus lactis Growth and Bacteriocin Production. Applied and Environmental Microbiology, 65, 291-293. 
[4] Booth, I.R. (1998) Bacterial Responses to Osmotic Stress: Diverse Mechanisms to Achieve a Common Goal. In: The Properties of Water in Foods, ISOPOW 6, Springer, Berlin, 456-485. https://doi.org/10.1007/978-1-4613-0311-4_21

[5] Obis, D., Guillot, A. Gripon, J.-C. Renault, P. Bolotin, A. and Mistou, M.-Y. (1999) Genetic and Biochemical Characterization of a High-Affinity Betaine Uptake System (BusA) in Lactococcus lactis Reveals a New Functional Organization within Bacterial ABC Transporters. Journal of Bacteriology, 181, 6238-6246.

[6] Rallu, F., Gruss, A. and Maguin, E. (1996) Lactococcus lactis and Stress. Antonie van Leeuwenhoek, 70, 243-251. https://doi.org/10.1007/BF00395935

[7] van de Guchte, M., Serror, P., Chervaux, C., Smokvina, T., Ehrlich, S.D. and Maguin, E. (2002) Stress Responses in Lactic Acid Bacteria. Antonie van Leeuwenhoek, 82, 187-216. https://doi.org/10.1023/A:1020631532202

[8] Cronan, J.E. (2002) Phospholipid Modifications in Bacteria. Current Opinion in Microbiology, 5, 202-205. https://doi.org/10.1016/S1369-5274(02)00297-7

[9] Smith, W.M., Dykes, G.A., Soomro, A.H. and Turner, M.S. (2010) Molecular Mechanisms of Stress Resistance in Lactococcus lactis. Current Research, Technology and Education Topics. Applied Microbiology and Microbial Biotechnology, 2, 1106-1118.

[10] Dobzhansky, T. (1968) On Some Fundamental Concepts of Darwinian Biology. In: Dobzhansky, T., Hecht, M. and Steere, W., Eds., Evolutionary Biology, Springer US, New York, 1-34. https://doi.org/10.1007/978-1-4684-8094-8_1

[11] Desmond, C., Stanton, C., Fitzgerald, G.F., Collins, K. and Paul Ross, R. (2002) Environmental Adaptation of Probiotic Lactobacilli towards Improvement of Performance during Spray Drying. International Dairy Journal, 12, 183-190. https://doi.org/10.1016/S0958-6946(02)00040-7

[12] De Angelis, M. and Gobbetti, M. (2004) Environmental Stress Responses in Lactobacillus: A Review. Proteomics, 4, 106-122. https://doi.org/10.1002/pmic.200300497

[13] Kim, W.S., Ren, J. and Dunn, N.W. (1999) Differentiation of Lactococcus lactis Subspecies Lactis and Subspecies Cremoris Strains by Their Adaptive Response to Stresses. FEMS Microbiology Letters, 171, 57-65. https://doi.org/10.1111/j.1574-6968.1999.tb13412.x

[14] Hartke, A., Bouche, S., Gansel, X., Boutibonnes, P. and Auffray, Y. (1994) Starvation-Induced Stress Resistance in Lactococcus lactis subsp. Lactis IL1403. Applied and Environmental Microbiology, 60, 3474-3478.

[15] Sanders, J.W., Kok, J. and Venema, G. (1999) Environmental Stress Responses in Lactococcus lactis. FEMS Microbiology Reviews, 23, 483-501. https://doi.org/10.1111/j.1574-6976.1999.tb00409.x

[16] Pichereau, V., Hartke, A. and Auffray, Y. (2000) Starvation and Osmotic Stress Induced Multiresistances: Influence of Extracellular Compounds. International Journal of Food Microbiology, 55, 19-25. https://doi.org/10.1016/S0168-1605(00)00208-7

[17] Giard, J.-C., Hartke, A., Flahaut, S., Benachour, A., Boutibonnes, P. and Auffray, Y. (1996) Starvation-Induced Multiresistance in Enterococcus faecalis JH2-2. Current Microbiology, 32, 264-271. https://doi.org/10.1007/s002849900048

[18] Kim, W.S., Park, J.H., Tandianus, J.E., Ren, J., Su, P. and Dunn, N.W. (2002) A Distinct Physiological State of Lactococcus lactis Cells That Confers Survival against a Direct and Prolonged Exposure to Severe Stresses. FEMS Microbiology Letters, 212, 203-208. https://doi.org/10.1111/j.1574-6968.2002.tb11267.x 
[19] Gutierrez, C., Abee, T. and Booth, I.R. (1995) Physiology of the Osmotic Stress Response in Microorganisms. International Journal of Food Microbiology, 28, 233-244. https://doi.org/10.1016/0168-1605(95)00059-3

[20] Molenaar, D., Hagting, A., Alkema, H., Driessen, A. and Konings, W.N. (1993) Characteristics and Osmoregulatory Roles of Uptake Systems for Proline and Glycine Betaine in Lactococcus lactis. Journal of Bacteriology, 175, 5438-5444. https://doi.org/10.1128/jb.175.17.5438-5444.1993

[21] Le Marrec, C. (2011) Responses of Lactic Acid Bacteria to Osmotic Stress. In: Stress Responses of Lactic Acid Bacteria, Springer, Berlin, 67-90. https://doi.org/10.1007/978-0-387-92771-8_4

[22] Kilstrup, M., Jacobsen, S., Hammer, K. and Vogensen, F.K. (1997) Induction of Heat Shock Proteins DnaK, GroEL, and GroES by Salt Stress in Lactococcus lactis. Applied and Environmental Microbiology, 63, 1826-1837.

[23] Engelmann, S. and Hecker, M. (1996) Impaired Oxidative Stress Resistance of Bacillus subtilis sigB Mutants and the Role of katA and katE. FEMS Microbiology Letters, 145, 63-69. https://doi.org/10.1111/j.1574-6968.1996.tb08557.x

[24] Lou, Y. and Yousef, A.E. (1996) Resistance of Listeria monocytogenes to Heat after Adaptation to Environmental Stresses. Journal of Food Protection, 59, 465-471. https://doi.org/10.4315/0362-028X-59.5.465

[25] Jenkins, D., Chaisson, S. and Matin, A. (1990) Starvation-Induced cross Protection against Osmotic Challenge in Escherichia coli. Journal of Bacteriology, 172, 2779-2781. https://doi.org/10.1128/jb.172.5.2779-2781.1990 